\section{The need for stronger child restraint laws}

To the Editor: Children are vulnerable road users in South Africa (SA), with road traffic crashes being the second leading cause of death for children aged 5 - 14 years. ${ }^{[1]}$ Two road-user groups, child pedestrians and child passengers, are particularly vulnerable, constituting $62 \%$ and $36 \%$ of child road fatalities, respectively. ${ }^{[2]}$ Several interventions have been proposed to reduce this preventable burden, including the appropriate use of child restraints. Evidence shows that, when installed correctly, child restraints can reduce the likelihood of a road traffic fatality by between $54 \%$ and $80 \%$, depending on the child's age. ${ }^{[3]}$

Two observational studies conducted at Red Cross War Memorial Children's Hospital, Cape Town, in 2008 and 2019 found that a concerning number of children arriving at the hospital by car were not restrained - in an age-appropriate child restraint system or by a seatbelt. ${ }^{[4,5]}$ While the findings in 2008 were expected because SA had no child restraint law at that time, the 2019 results are disappointing because of the 2014 amendment to the road safety law, which requires the use of a child restraint. The amendment to regulation 213, section 6A of National Road Traffic Act No. 93 of $1996^{[6]}$ mandates the use of a South African Bureau of Standards-approved child restraint for all child passengers under the age of 3 years and also requires children aged 3 years and older to sit in the rear and use a seatbelt.

Child restraint use can be increased significantly by applying a systems approach that includes adequate enforcement of the law. ${ }^{[5]} \mathrm{We}$ decided to review the SA Road Traffic Act and associated regulations, to determine whether the existing legislation and associated penalties are comprehensive without any ambiguity or loopholes that might enable road users to escape the consequences of breaking the law.

Our review identified three main issues. Firstly, the law remains ambiguous on the type of restraint that should be used for children older than 3 years, and does not comply with international best practice as defined by the United Nations Economic Commission for Europe regulation 44 or the latest version, regulation 129. ${ }^{[7]}$ Furthermore, the SA law in its current state gives no indication as to the best position for a child under the age of 3 to sit in a car with his/her child restraint, i.e. the back seat or the front seat. The bestpractice law categorises restraints suitable for a child up to the age of 12 years based on three factors: age, height and weight. Furthermore, older children who are above the height and weight specification must wear a seatbelt. International law further states that a child must be restrained in the back seat ${ }^{[7]}$ in order to minimise injury during a road crash.

Our second finding was that the age specification in the SA law imposes the challenging task of age estimation on law enforcement officials, which results in low restraint use. A study in 2002 found that $87 \%$ of observers were able to estimate the age of a child correctly, mainly because they had previously worked with children and had been given age estimation training. ${ }^{[8]}$

Lastly, a review of current police penalties associated with the legislation indicates that the fine for non-compliance with child restraint use is only ZAR250. ${ }^{[9]}$ In the UK, parents (or guardians) who do not comply with the child restraint law, or use an inappropriate form of restraint, can be fined up to GBP500 ${ }^{[10]}$ ( ZAR9 200), which is almost 37 times more than the SA penalty. Even when taking the income disparity between the two countries into consideration, the fine in SA - which is less than the cost of a tank of petrol - is too low to force drivers to abide by the law.

Our findings suggest that there is a need for: (i) improved specification in the legislation on the correct form of restraint to be used for children in different age categories; (ii) improved training for enforcement officers on age estimation and correct child restraint installation and usage; and (iii) an increase in the amount of the fine, or a more punitive form of enforcement. These recommendations would go a long way towards increasing child restraint use in SA, with the ultimate goal of having SA law comply with good international practice in United Nations Regulation 129. ${ }^{[7]}$

\section{Aliasgher Janmohammed \\ Centre for Transport Studies, Department of Civil Engineering, Faculty of Engineering and the Built Environment, University of Cape Town, South Africa \\ aliasgher.janmohammed@uct.ac.za}

\section{Prasanthi Attwood}

George Institute of Global Health, Oxford, UK

\section{Pumla Mtambeka}

ChildSafe South Africa, Red Cross War Memorial Children's Hospital, Cape Town, South Africa

\section{Megan Prinsloo}

Medical Research Council, Cape Town, South Africa

\section{Margie Peden}

George Institute of Global Health, Oxford, UK

1. Msemburi W, Pillay-van Wyk V, Dorrington RE, et al. Second National Burden of Disease Study for South Africa: Cause-of-death Profile for South Africa, 1997 - 2012. Cape Town: South African Medical South Africa: Cause-of-de
Research Council, 2016.

2. Janmohammed A, Vanderschuren V, Clay C. Analysis of Current Road Injury and Fatality Data. Prepared for ChildSafe South Africa and UNICEF. Cape Town: University of Cape Town, 2019

3. World Health Organization. Ten Strategies for Keeping Children Safe on the Road. WHO, 2015. https:/ www.who.int/roadsafety/week/2015/Ten_Strategies_For_Keeping_Children_Safe_on_the_Road.pdf (accessed 12 June 2019).

4. Kling J, Nicholls T, Ntambeka P, van As AB. Restraint use for child passengers in South Africa. S Afr Med J 2011;101(3):146

Clay C, van As AB, Hunter K, Peden M. Latest results show urgent need to address child restraint use. S Afr Med J 2019;109(2):66. https://doi.org/10.7196/SAMJ.2019.v109i2.13831

6. South Africa. National Road Traffic Act No. 93 of 1996. Amendment of the National Road Traffic 6. Regulations. Government Gazette No. 38142, 2014. https:/

7. United Nations. UN Regulation No. 129. Increasing the Safety of Children in Vehicles for Policy Makers and Concerned Citizens. Geneva: Economic Commission for Europe (UNECE), 2016. https://www. and Concerned Citizens. Geneva: Economic Commission for Europe (UNECE), 2016. https://wWw.
unece.org/fileadmin/DAM/trans/publications/WP29/CHILD_RESTRAINT_SYSTEMS_brochure.pdf unece.org/fileadmin/DAM
(accessed 12 June 2019).

8. Moeller S, Berger L, Salvador JG, Helitzer D. How old is that child? Validating the accuracy of age assignments in observational surveys of vehicle restraint use. Injury Prev 2002;8(3):248-251. https://doi. org/10.1136/ip.8.3.248

9. Arrive Alive. South African law on wearing of seatbelts. https://www.arrivealive.co.za/South-AfricanLaw-on-Wearing-of-Seatbelts (accessed 10 April 2019).

10. Diebelius G. New car seat laws mean you could be fined $£ 500$. Metro News. 2017. https://metro. co.uk/2017/02/28/new-car-seat-laws-mean-you-could-be-fined-500-6477924/ (accessed 10 April 2019).

S Afr Med J 2019;109(8):545. DOI:10.7196/SAMJ.2019.v109i8.14118 